\title{
Ion-Solvent Interactions Investigated by Isentropic Compressibility Measurements of Tetraalkylammonium, Copper(I) and Sodium Salts in Binary Mixtures of Acetonitrile and $\boldsymbol{n}$-Butyronitrile at $298.15 \mathrm{~K}$
}

\author{
Dip Singh Gill, Avnesh Kumari, Surinder Kumar Sharma, and Surinder Pal Jauhar \\ Department of Chemistry, Panjab University, Chandigarh - 160 014, India \\ Reprint requests to Dr. D. S. G.; Fax: 91-172-2545074; E-mail: dipgill@yahoo.com \\ Z. Naturforsch. 60a, 70-74 (2005); received August 26, 2004
}

Ultrasonic velocities and densities of binary mixtures of acetonitrile (AN) and $n$-butyronitrile (n-BTN) with $\mathrm{Bu}_{4} \mathrm{NBPh}_{4}, \mathrm{Bu}_{4} \mathrm{NClO}_{4}, \mathrm{Bu}_{4} \mathrm{NI}, \mathrm{Bu}_{4} \mathrm{NBr}, \mathrm{Pr}_{4} \mathrm{NBr}, \mathrm{Et}_{4} \mathrm{NI}, \mathrm{Et}_{4} \mathrm{NBPh}_{4}, \mathrm{NaBPh}_{4}$, $\mathrm{NaClO}_{4}$ and $\mathrm{CuClO}_{4}$ have been measured in the concentration range $0.0045-0.2 \mathrm{~mol} \mathrm{~kg}^{-1}$ over the entire composition range at $298.15 \mathrm{~K}$. Isentropic compressibilities $\left(K_{\mathrm{s}}\right)$ and apparent molal isentropic compressibilities $\left(K_{\mathrm{S}, \phi}\right)$ have been calculated. Limiting apparent molal isentropic compressibilities $\left(K_{\mathrm{s}, \phi}^{\mathrm{o}}\right)$ have been evaluated and split into the contribution of individual ions, i. e. into $\left(K_{\mathrm{s}, \phi}^{\mathrm{o}}\right)_{ \pm}$values. $\left(K_{\mathrm{s}, \phi}^{\mathrm{o}}\right)_{ \pm}$for $\mathrm{Cu}^{+}, \mathrm{Na}^{+}$and $\mathrm{Br}^{-}$in all cases is negative and large, for $\mathrm{Bu}_{4} \mathrm{~N}^{+}$and $\mathrm{Ph}_{4} \mathrm{~B}^{-}$positive and large, and for $\mathrm{I}^{-}$and $\mathrm{ClO}_{4}{ }^{-}$negative only in $\mathrm{AN}$, and becomes positive in binary mixtures of $\mathrm{AN}$ and $n$-BTN for all compositions. The negative $\left(K_{\mathrm{s}, \phi}^{\mathrm{o}}\right)_{ \pm}$values for $\mathrm{Cu}^{+}, \mathrm{Na}^{+}$and $\mathrm{Br}^{-}$indicate strong ionsolvent interactions involving electrostatic ion-dipole interactions. The large and positive $\left(K_{\mathrm{s}, \phi}^{\mathrm{o}}\right)_{ \pm}$ values for $\mathrm{Bu}_{4} \mathrm{~N}^{+}$and $\mathrm{Ph}_{4} \mathrm{~B}^{-}$show some special type of ion-solvent interactions (hydrophobic or dispersion interactions) with $\mathrm{AN}$ and $n$-BTN. The small negative value changing to a small positive value for $\mathrm{I}^{-}$and $\mathrm{ClO}_{4}{ }^{-}$indicates the change of a weak electrostatic ion-solvent interaction to another weak special interaction. A comparison of $\left(K_{\mathrm{s}, \phi}^{\mathrm{o}}\right)_{ \pm}$for $\mathrm{Cu}^{+}$in some solvent systems shows that the ion-solvent interaction behaviour of $\mathrm{Cu}^{+}$in $\mathrm{AN}+n$ - $\mathrm{BTN}$ is similar to that in $\mathrm{AN}+\mathrm{NM}$, AN + TEP, $\mathrm{BN}+\mathrm{TEP}$ and $\mathrm{PY}+\mathrm{TEP}$ mixtures but differs from that observed in $\mathrm{AN}+\mathrm{DMF}$ and $\mathrm{AN}+\mathrm{DMSO}$ mixtures.

Key words: Ion-Solvent Interaction; Isentropic Compressibility; Copper(I) Salts; Acetonitrile; $n$-Butyronitrile.

\section{Introduction}

Ion-solvent interactions have been extensively investigated $[1-6]$ in a number of mixed solvents using different techniques. Alkali ions interact with solvent molecules purely through electrostatic forces [7,8]. $\mathrm{Cu}^{+}$and $\mathrm{Ag}^{+}$ions interact with nitrile solvents also through a special type of interactions [9-11]. Limiting ionic apparent molal isentropic compressibilities $\left(K_{\mathrm{s}, \phi}^{\mathrm{o}}\right)_{ \pm}[12-14]$ are important parameters which not only provide the magnitude but also predict the nature of the interactions on the basis of their positive or negative sign. Even hydrophobic interactions, taking place between tetraalkylammonium ions and solvent molecules, can be identified by evaluation of their $\left(K_{\mathrm{s}, \phi}^{\mathrm{o}}\right)_{ \pm}$values. In the present work, ion-solvent interactions have been measured in some copper(I), sodium and tetraalkylammonium salts by their isentropic compressibilities. AN and $n$-BTN mixtures are selected for these studies, because these solvents have different dielectric constants $\left(\varepsilon_{\mathrm{AN}}=36.0, \varepsilon_{n-\mathrm{BTN}}=24.8\right)$ but similar $-\mathrm{C} \equiv \mathrm{N}$ groups, and are expected to interact with the ions through a different extent of electrostatic but similar special interactions.

\section{Experimental}

AN $99.5 \%$ and $n$-BTN $99.5 \%$ (both E. Merck) were purified as reported in [15]. The purified solvents had the densities 0.77685 and $0.78662 \mathrm{~g} \mathrm{~cm}^{-3}$, viscosities 0.341 and $0.551 \mathrm{cP}$, and ultrasonic velocities 1280.8 and $1279.0 \mathrm{~m} \mathrm{~s}^{-1}$, respectively, which agreee well with the literature values [15].

Copper(I) perchlorate tetraacetonitrile $\left(\left[\mathrm{Cu}\left(\mathrm{CH}_{3}-\right.\right.\right.$ $\left.\mathrm{CN})_{4}\right] \mathrm{ClO}_{4}$ ) was prepared by the reduction of copper(II) perchlorate hexahydrate by copper powder in warm AN, following the method reported by Hathaway et al. [16] and Gill et al. [17]. The purity 
of the complex was checked by its elemental and chemical analysis. Tetrabutylammonium tetraphenylborate $\left(\mathrm{Bu}_{4} \mathrm{NBPh}_{4}\right)$ and tetrabutylammonium perchlorate $\left(\mathrm{Bu}_{4} \mathrm{NClO}_{4}\right)$ (used as reference electrolytes in the present work), anhydrous sodium perchlorate $\left(\mathrm{NaClO}_{4}\right)$ and tetraethylammonium tetraphenylborate $\left(\mathrm{Et}_{4} \mathrm{NBPh}_{4}\right)$ were prepared by the methods given in [18]. $\mathrm{NaBPh}_{4}, 99.5 \%$ (E. Merck), $\mathrm{Bu}_{4} \mathrm{NI}, \mathrm{Bu}_{4} \mathrm{NBr}$, $\mathrm{Pr}_{4} \mathrm{NBr}$ and $\mathrm{Et}_{4} \mathrm{NI}$ (all $>99 \%$, from Fluka) were used as received.

Ultrasonic velocity measurements of the binary mixtures as well as of all salt solutions were carried out at $2 \mathrm{MHz}$ frequency with an ultrasonic time intervalometer (Model UTI-101), manufactured by Innovative Instruments (Hyderabad), using a pulse echo overlap technique. Different concentrations of the salts in $\mathrm{AN}+n$-BTN mixtures were prepared by diluting the stock solutions. In all cases the measurements were performed twice. The densities were measured using a precision densitimeter (Anton Paar model DMA60 with an external measuring cell DMA-602). The absolute accuracy of the sound velocity and density measurements was better than $\pm 2 \times 10^{-4} \mathrm{~m} \mathrm{~s}^{-1}$ and $\pm 1 \times 10^{-5} \mathrm{~g} \mathrm{~cm}^{-3}$, respectively, as reported in [13].

\section{Results and Discussion}

The Physical parameters of the $\mathrm{AN}+n$-BTN binary mixtures of varying compositions are reported in Table 1 , which shows that density $\left(\rho_{\mathrm{o}}\right)$, viscosity $\left(\eta_{\mathrm{o}}\right)$ and ultrasonic velocity $\left(u_{\mathrm{o}}\right)$ of all binary mixtures vary over a wide range. The ultrasonic velocities $(u)$ and densities $(\rho)$ of $\mathrm{Bu}_{4} \mathrm{NBPh}_{4}, \mathrm{Bu}_{4} \mathrm{NClO}_{4}$, $\mathrm{Bu}_{4} \mathrm{NI}, \mathrm{Bu}_{4} \mathrm{NBr}, \mathrm{Pr}_{4} \mathrm{NBr}, \mathrm{Et}_{4} \mathrm{NI}, \mathrm{Et}_{4} \mathrm{NBPh}_{4}, \mathrm{NaBPh}_{4}$, $\mathrm{NaClO}_{4}$ and $\mathrm{CuClO}_{4}$ have been measured at different salt molalities $(m)$ in the molality range 0.0045 to $0.2 \mathrm{~mol} \mathrm{~kg}^{-1}$ in $\mathrm{AN}+n$-BTN mixtures containing $0,20,40,60,80$ and $100 \mathrm{~mol} \% \mathrm{AN}$. The isentropic compressibility $\left(K_{\mathrm{s}}\right)$ of each electrolyte in each solvent has been calculated by using the relation

$$
K_{\mathrm{S}}=\frac{1}{u^{2} \rho} .
$$

The apparent molal isentropic compressibility $\left(K_{\mathrm{s}, \phi}\right)$ of these salts has been calculated using the partial molal volume $V_{\phi}$ and the equations

$$
V_{\phi}=\frac{M}{\rho}-\frac{10^{3}\left[\rho-\rho_{\mathrm{o}}\right]}{m \rho \rho_{\mathrm{o}}} \text {, }
$$

Table 1 . Viscosity $\left(\eta_{\mathrm{o}}\right)$, density $\left(\rho_{\mathrm{o}}\right)$, permittivity $\left(\varepsilon_{\mathrm{o}}\right)$, ultrasonic velocity $\left(u_{\mathrm{o}}\right)$ and isentropic compressibility $\left(K_{\mathrm{s}}^{\mathrm{O}}\right)$ for $\mathrm{AN}+n$-BTN mixtures at $298.15 \mathrm{~K}$.

\begin{tabular}{cccccc}
\hline $\mathrm{mol} \% \mathrm{AN}$ & $\eta_{\mathrm{o}} / \mathrm{cP}$ & $\rho_{\mathrm{o}} / \mathrm{g} \mathrm{cm}^{-3}$ & $\varepsilon_{\mathrm{o}}$ & $u_{\mathrm{o}} / \mathrm{ms}^{-1}$ & $10^{6} K_{\mathrm{s}}^{\mathrm{o}} / \mathrm{bar}^{-1}$ \\
\hline 100 & 0.341 & 0.77685 & 36.0 & 1280.8 & 78.47 \\
80 & 0.405 & 0.78054 & 33.9 & 1276.6 & 78.61 \\
60 & 0.428 & 0.78125 & 32.5 & 1276.7 & 78.52 \\
40 & 0.467 & 0.78379 & 30.8 & 1277.4 & 78.19 \\
20 & 0.510 & 0.78547 & 28.9 & 1278.8 & 77.86 \\
0 & 0.553 & 0.78662 & 24.8 & 1279.0 & 77.71 \\
\hline
\end{tabular}

$$
K_{\mathrm{s}, \phi}=V_{\phi} K_{\mathrm{s}}+\frac{10^{3}\left[K_{\mathrm{s}}-K_{\mathrm{o}}\right]}{m \rho_{\mathrm{o}}},
$$

where $m$ is the molality and $M$ the molecular mass of the solute. $K_{\mathrm{S}}$ and $K_{\mathrm{o}}$ are the isentropic compressibilities of the solution and the pure solvent, and $\rho$ and $\rho_{\mathrm{o}}$ are the corresponding densities. The plots of $K_{\mathrm{s}, \phi}$ versus $m^{1 / 2}$ were linear in the concentration range studied. The limiting apparent molal isentropic compressibilities $\left(K_{\mathrm{s}, \phi}^{\mathrm{o}}\right)$ were obtained by extrapolation from the linear plots of $K_{\mathrm{s}, \phi}$ versus $m^{1 / 2}$ by the least squares method using the equation

$$
K_{\mathrm{s}, \phi}=K_{\mathrm{s}, \phi}^{\mathrm{o}}+A_{\mathrm{s}, \phi} m^{1 / 2} .
$$

The $K_{\mathrm{s}, \phi}^{\mathrm{o}}$ values of the various salts thus obtained are reported in Table 2.

The $K_{\mathrm{s}, \phi}^{\mathrm{o}}$ values of these electrolytes are not available for $\mathrm{AN}+n$-BTN mixtures. Therefore a comparison of our values could not be made. In pure $\mathrm{AN}$, the $K_{\mathrm{s}, \phi}^{\mathrm{o}}$ values for $\mathrm{Bu}_{4} \mathrm{NBPh}_{4}(106.5 \times$ $\left.10^{-4} \mathrm{~cm}^{3} \mathrm{~mol}^{-1} \mathrm{bar}^{-1}\right)$ and for $\mathrm{Bu}_{4} \mathrm{NClO}_{4}(22.6 \times$ $10^{-4} \mathrm{~cm}^{3} \mathrm{~mol}^{-1} \mathrm{bar}^{-1}$ ) agree within $\pm 2.6 \times$ $10^{-4} \mathrm{~cm}^{3} \mathrm{~mol}^{-1} \mathrm{bar}^{-1}$ with the values $108.0 \times$ $10^{-4} \mathrm{~cm}^{3} \mathrm{~mol}^{-1} \mathrm{bar}^{-1}$ and $20.0 \times 10^{-4} \mathrm{~cm}^{3} \mathrm{~mol}^{-1}$ bar $^{-1}$, respectively [19].

Table 2 shows that the $K_{\mathrm{s}, \phi}^{\mathrm{o}}$ values for copper(I) perchlorate and sodium perchlorate are negative and large in $\mathrm{AN}+n$-BTN mixtures at all compositions of the solvent mixtures. For $\mathrm{Bu}_{4} \mathrm{NBPh}_{4}, \mathrm{Bu}_{4} \mathrm{NClO}_{4}, \mathrm{Bu}_{4} \mathrm{NI}$, $\mathrm{Bu}_{4} \mathrm{NBr}, \mathrm{Pr}_{4} \mathrm{NBr}, \mathrm{Et}_{4} \mathrm{NBPh}_{4}$ except for $\mathrm{NaBPh}_{4}, K_{\mathrm{s}, \phi}^{\mathrm{o}}$ is mostly positive and large at all compositions. $\mathrm{Et}_{4} \mathrm{NI}$ has a negative $K_{\mathrm{s}, \phi}^{\mathrm{o}}$ value in $\mathrm{AN}+n$-BTN mixtures, which decreases with increase in mol\% of $n$-BTN.

For obtaining quantitative information regarding the tendency of each ion to produce structural or solvation effects, the $K_{\mathrm{s}, \phi}^{\mathrm{o}}$ values for the salts in Table 2 have been split into contributions of individual ions, $i$. e. into ionic $K_{\mathrm{s}, \phi}^{\mathrm{o}}$ values.

As reported in [20-23], the $K_{\mathrm{s}, \phi}^{\mathrm{o}}$ values are additive and can be split that way. For that splitting of 


\begin{tabular}{lcccccc}
\hline \multicolumn{7}{c}{$\left(K_{\mathrm{s}, \phi}^{\mathrm{o}}\right) / 10^{-4} \mathrm{~cm}^{3} \mathrm{~mol}^{-1} \mathrm{bar}^{-1}$} \\
$\mathrm{~mol} \% \mathrm{AN}$ & & \\
$\mathrm{Salt}$ & 100 & 80 & 60 & 40 & 20 & 0 \\
\hline $\mathrm{Bu}_{4} \mathrm{NBPh}_{4}$ & 106.5 & 160.0 & 372.8 & 373.9 & 402.1 & 412.1 \\
$\mathrm{Bu}_{4} \mathrm{NClO}_{4}$ & 22.6 & 108.0 & 220.5 & 235.7 & 249.7 & 290.8 \\
$\mathrm{Bu}_{4} \mathrm{NI}$ & 12.0 & 79.0 & 184.0 & 196.0 & 235.9 & 295.1 \\
$\mathrm{Bu}_{4} \mathrm{NBr}$ & 9.4 & 36.9 & 135.5 & 138.0 & 179.0 & 268.5 \\
$\mathrm{Pr}_{4} \mathrm{NBr}$ & -44.4 & -34.0 & 112.0 & 123.0 & 133.0 & 238.2 \\
$\mathrm{Et}_{4} \mathrm{NI}$ & -103.8 & -48.2 & -25.2 & -12.4 & 19.9 & 86.3 \\
& $(-103.5)^{\mathrm{b}}$ & $(-47.0)^{\mathrm{b}}$ & $(-24.8)^{\mathrm{b}}$ & $(-10.5)^{\mathrm{b}}$ & $(19.1)^{\mathrm{b}}$ & $(84.7)^{\mathrm{b}}$ \\
$\mathrm{Et}_{4} \mathrm{NBPh}_{4}$ & -9.0 & 34.0 & 164.0 & 167.4 & 185.3 & 201.7 \\
$\mathrm{NaBPh}_{4}$ & -92.2 & -136.3 & -48.1 & -77.5 & -74.1 & -133.8 \\
& $(-92.3)^{\mathrm{b}}$ & $(-134.9)^{\mathrm{b}}$ & $(-48.1)^{\mathrm{b}}$ & $(-75.3)^{\mathrm{b}}$ & $(-72.1)^{\mathrm{b}}$ & $(-133.4)^{\mathrm{b}}$ \\
$\mathrm{NaClO}_{4}$ & -176.2 & -186.9 & -200.4 & -213.0 & -224.5 & -254.7 \\
$\mathrm{CuClO}_{4}$ & -212.0 & -219.9 & -250.0 & -280.5 & -300.4 & -351.8 \\
\hline
\end{tabular}

Table 2. Limiting apparent molal isentropic compressibilities ${ }^{\mathrm{a}}$ $\left(K_{\mathrm{s}, \phi}^{\mathrm{o}}\right)$ for some salts in $\mathrm{AN}+n$ BTN mixtures at $298.15 \mathrm{~K}$.

${ }^{a}$ Maximum uncertainity in these values is $\pm 2.6 \times 10^{-4} \mathrm{~cm}^{3} \mathrm{~mol}^{-1} \mathrm{bar}^{-1}$. b These values have been obtained by adding $\left(K_{\mathrm{s}, \phi}^{\mathrm{o}}\right)_{ \pm}$for the respective ions constituting the salts.

$K_{\mathrm{s}, \phi}^{\mathrm{o}}$ some approaches in [20] have been utilized. The method already used in AN is based upon $\left(K_{\mathrm{s}, \phi}^{\mathrm{o}}\right)_{ \pm}$for $\mathrm{Ph}_{4} \mathrm{~B}^{-}=0$. This method is not appropriate because $\mathrm{Ph}_{4} \mathrm{~B}^{-}$is large $(0.535 \mathrm{~nm})$, even larger than $\mathrm{Bu}_{4} \mathrm{~N}^{+}$ $(0.50 \mathrm{~nm})$ [21]. Therefore its contribution to the compressibility cannot be neglected. Millero [22] has split the partial molal volumes of electrolytes into ionic components using $\mathrm{Ph}_{4} \mathrm{AsBPh}_{4}$ as a reference electrolyte. A similar model in [23], in which it is recommended to use $\mathrm{Bu}_{4} \mathrm{NBPh}_{4}$ as reference electrolyte to achieve the splitting of the $K_{\mathrm{s}, \phi}^{\mathrm{o}}$ values into their ionic contributions $\left(K_{\mathrm{s}, \phi}^{\mathrm{o}}\right)_{ \pm}$with the help of the equations

$$
\begin{gathered}
\frac{K_{\mathrm{s}, \phi}^{\mathrm{o}}\left(\mathrm{Bu}_{4} \mathrm{~N}^{+}\right)}{K_{\mathrm{s}, \phi}^{\mathrm{o}}\left(\mathrm{Ph}_{4} \mathrm{~B}^{-}\right)}=\frac{r_{\mathrm{c}}^{3}\left(\mathrm{Bu}_{4} \mathrm{~N}^{+}\right)}{r_{\mathrm{c}}^{3}\left(\mathrm{Ph}_{4} \mathrm{~B}^{-}\right)}=\left(\frac{5.00}{5.35}\right)^{3} \\
K_{\mathrm{s}, \phi}^{\mathrm{o}}\left(\mathrm{Bu}_{4} \mathrm{NBPh}_{4}\right)=K_{\mathrm{s}, \phi}^{\mathrm{o}}\left(\mathrm{Bu}_{4} \mathrm{~N}^{+}\right)+K_{\mathrm{s}, \phi}^{\mathrm{o}}\left(\mathrm{Ph}_{4} \mathrm{~B}^{-}\right)
\end{gathered}
$$

Using (5) and (6), the $K_{\mathrm{s}, \phi}^{\mathrm{o}}$ values of $\mathrm{Bu}_{4} \mathrm{NBPh}_{4}$ were split into contribution of $\mathrm{Bu}_{4} \mathrm{~N}^{+}$and $\mathrm{Ph}_{4} \mathrm{~B}^{-}$ions. By using these $\left(K_{\mathrm{s}, \phi}^{\mathrm{o}}\right)_{ \pm}$values, such values for all other ions have been calculated and are reported in Table 3.

The consistency of the present results can be checked by comparing the experimental $\left(K_{\mathrm{s}, \phi}^{\mathrm{o}}\right)$ values for $\mathrm{Et}_{4} \mathrm{NI}$ and $\mathrm{NaBPh}_{4}$ from Table 2 with the $\left(K_{\mathrm{s}, \phi}^{\mathrm{o}}\right)$ values obtained by adding up the $\left(K_{\mathrm{s}, \phi}^{\mathrm{o}}\right)_{ \pm}$values for the respective ions constituting the salts. The added up values for $\mathrm{Et}_{4} \mathrm{NI}$ and $\mathrm{NaBPh}_{4}$ from Table 3 are written in parantheses in Table 2. Good agreement (within $\pm 2.5 \times 10^{-4} \mathrm{~cm}^{3} \mathrm{~mol}^{-1} \mathrm{bar}^{-1}$ ) has been observed between the experimental and added up values.

Negative $\left(K_{\mathrm{s}, \phi}^{\mathrm{o}}\right)$ values are generally obtained due to stronger ion-solvent interactions involving electrostatic ion-dipoles, or some special type of interactions, while positive values are obtained mostly for tetra-
Table 3. Limiting ionic apparent molal isentropic compressibilities $\left(K_{\mathrm{s}, \phi}^{\mathrm{o}}\right)_{ \pm}$for some ions in $\mathrm{AN}+n$-BTN mixtures at $298.15 \mathrm{~K}$

\begin{tabular}{lrrrrrr}
\hline \multicolumn{7}{c}{$\left(K_{\mathrm{s}, \phi}^{\mathrm{o}}\right)_{ \pm} / 10^{-4} \mathrm{~cm}^{3} \mathrm{~mol}^{-1} \mathrm{bar}^{-1}$} \\
$\mathrm{Ion}$ & 100 & \multicolumn{7}{c}{80} & 60 & \multicolumn{1}{c}{40} & 20 & \multicolumn{1}{c}{0} \\
\hline $\mathrm{Bu}_{4} \mathrm{~N}^{+}$ & 47.8 & 71.9 & 167.5 & 168.0 & 180.7 & 185.2 \\
$\mathrm{Pr}_{4} \mathrm{~N}^{+}$ & -6.0 & 1.0 & 144.0 & 153.0 & 134.7 & 154.9 \\
$\mathrm{Et}_{4} \mathrm{~N}^{+}$ & -67.7 & -54.1 & -41.3 & -38.5 & -36.1 & -25.2 \\
$\mathrm{Cu}^{+}$ & -186.8 & -256.1 & -303.0 & -348.7 & -369.4 & -457.4 \\
$\mathrm{Na}^{+}$ & -151.0 & -223.0 & -253.4 & -281.2 & -293.5 & -360.3 \\
$\mathrm{Ph}_{4} \mathrm{~B}^{-}$ & 58.7 & 88.1 & 205.3 & 205.9 & 221.4 & 226.9 \\
$\mathrm{I}^{-}$ & -35.8 & 7.1 & 16.5 & 28.0 & 55.2 & 109.9 \\
$\mathrm{ClO}_{4}{ }^{-}$ & -25.2 & 36.1 & 53.0 & 68.2 & 69.0 & 105.6 \\
$\mathrm{Br}^{-}$ & -38.4 & -35.0 & -32.0 & -30.0 & -1.7 & 83.3 \\
\hline
\end{tabular}

alkylammonium ions due to hydrophobic or dispersive interactions. The results of Table 3 show that the $\left(K_{\mathrm{s}, \phi}^{\mathrm{o}}\right)_{ \pm}$values for $\mathrm{Cu}^{+}, \mathrm{Na}^{+}$and $\mathrm{Br}^{-}$are negative. For $\mathrm{Cu}^{+}$and $\mathrm{Na}^{+}$their magnitude is quite large, but for $\mathrm{Br}^{-}$it is relatively small. The results indicate that $\mathrm{Cu}^{+}$ and $\mathrm{Na}^{+}$ions have strong ion-solvent interactions as compared to $\mathrm{Br}^{-}$in all these mixtures. For $\mathrm{Cu}^{+}$and $\mathrm{Na}^{+}$the extent of ion-solvent interactions increases with increase of the $n$-BTN composition, while but for $\mathrm{Br}^{-}$it decreases. The $\left(K_{\mathrm{s}, \phi}^{\mathrm{o}}\right)_{ \pm}$values for $\mathrm{Bu}_{4} \mathrm{~N}^{+}$and $\mathrm{Ph}_{4} \mathrm{~B}^{-}$are positive and large at all compositions of the mixtures. These $\left(K_{\mathrm{s}, \phi}^{\mathrm{o}}\right)_{ \pm}$values indicate some special type of ion-solvent interaction, which may take place due to hydrophobic dispersion or solvent-solvent interactions. The hydrophobic interaction with increase of the $n$-BTN composition increases due to the increased chain length of $n$-BTN. $\mathrm{I}^{-}$and $\mathrm{ClO}_{4}{ }^{-}$have negative $\left(K_{\mathrm{s}, \phi}^{\mathrm{o}}\right)_{ \pm}$values in pure $\mathrm{AN}$, and these values become positive in the $n$-BTN rich region. The magnitude of the $\left(K_{\mathrm{s}, \phi}^{\mathrm{o}}\right)_{ \pm}$values in both these cases is, however, small indicating poor solvation of both these ions in $\mathrm{AN}+n$-BTN mixtures. The ion-solvent interac- 


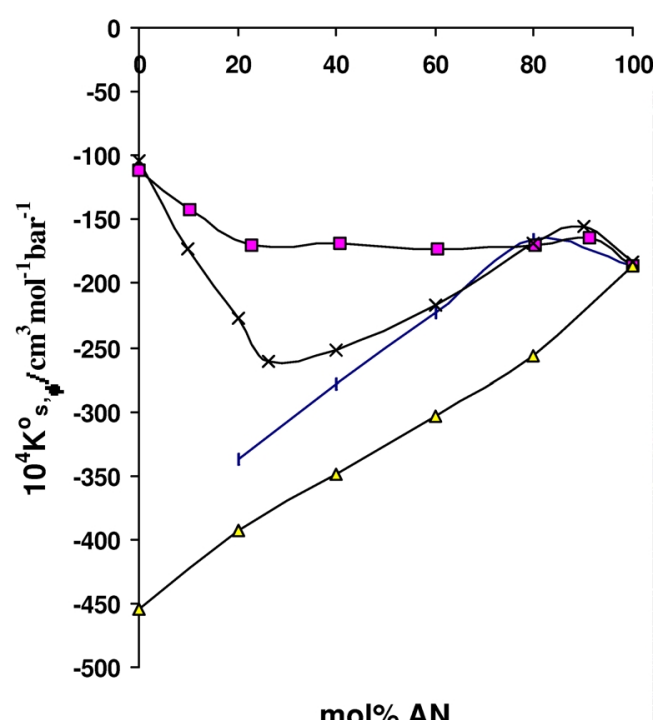

mol\% AN

Fig. 1. Plot of $\left(K_{\mathrm{s}, \phi}^{\mathrm{o}}\right)_{ \pm}$for $\mathrm{Cu}^{+}$versus mol\% $\mathrm{AN}$ in $\mathrm{AN}+$ $\mathrm{NM}(\boldsymbol{\square}), \mathrm{AN}+\mathrm{DMF}(\times), \mathrm{AN}+\mathrm{DMSO}(\mid)$, and $\mathrm{AN}+n-$ $\operatorname{BTN}(\triangle)$ mixtures.

tion for these ions changes from weak electrostatic to a special type of interaction in the $n$-BTN rich region. As special interaction of $\mathrm{Ph}_{4} \mathrm{As}^{+}$and $\mathrm{Ph}_{4} \mathrm{~B}^{-}$with $\mathrm{AN}$ through dispersion forces was also reported by Bose and Kundu [24].

For $\mathrm{Et}_{4} \mathrm{~N}^{+}$at all compositions and for $\operatorname{Pr}_{4} \mathrm{~N}^{+}$only in AN the $\left(K_{\mathrm{s}, \phi}^{\mathrm{o}}\right)_{ \pm}$values are negative, indicating the solvation of these two ions in these systems. The extent of ion-solvent interactions, however, decreases with the increase of the $n$-BTN concentration in the mixture.

The $\left(K_{\mathrm{s}, \phi}^{\mathrm{o}}\right)_{ \pm}$values for $\mathrm{Cu}^{+}$in some mixed solvents were recently reported in [4]. These results have been incorporated for comparing their ion-solvent interactions with the present system. Plots of $\left(K_{\mathrm{s}, \phi}^{\mathrm{o}}\right)_{ \pm}$for $\mathrm{Cu}^{+}$in some solvents mixtures as a function of the mol\% AN and TEP are presented in Figs. 1 and 2, respectively. The results show that $\left(K_{\mathrm{s}, \phi}^{\mathrm{o}}\right)_{ \pm}$for $\mathrm{Cu}^{+}$ becomes most negative between $20-60 \mathrm{~mol} \% \mathrm{AN}$ in $\mathrm{AN}+\mathrm{DMF}$ mixtures, passes through a minimum negative value at about $80 \mathrm{~mol} \% \mathrm{AN}$ in $\mathrm{AN}+\mathrm{DMSO}$ mixture and changes linearly in $\mathrm{AN}+n$-BTN, $\mathrm{AN}+\mathrm{TEP}$, $\mathrm{BN}+\mathrm{TEP}$ and PY + TEP mixtures with the value

[1] D. S. Gill, L. Rodehueser, P. Rubini, and J. J. Delpuech, J. Chem. Soc. Faraday Trans. 91, 2307 (1995).

[2] D. S. Gill, U. Kamp, A. Doelle, and M. D. Zeidler, Indian J. Chem. 40A, 693 (2001).

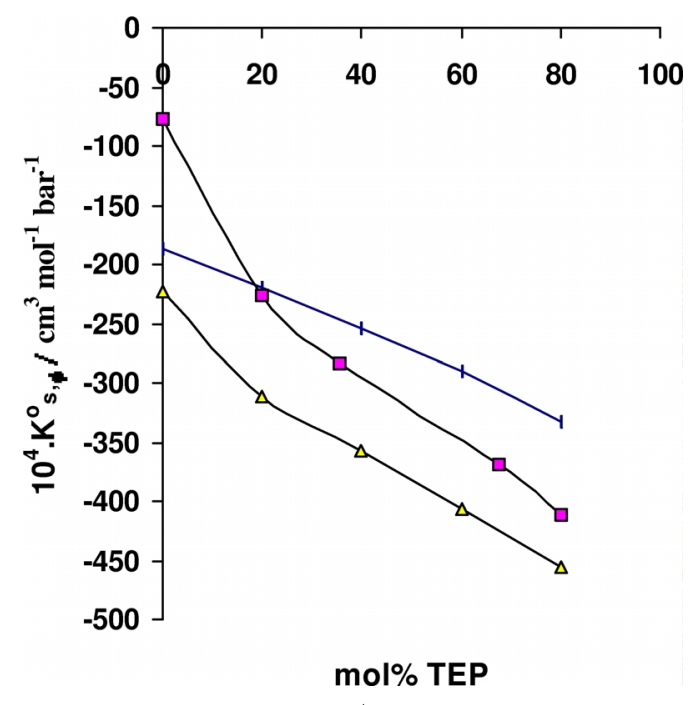

Fig. 2. Plot of $\left(K_{\mathrm{s}, \phi}^{\mathrm{o}}\right)_{ \pm}$for $\mathrm{Cu}^{+}$versus mol\% TEP in $\mathrm{AN}+$ $\operatorname{TEP}(\mid), \mathrm{BN}+\mathrm{TEP}(\boldsymbol{\square})$, and $\mathrm{PY}+\mathrm{TEP}(\triangle)$ mixtures.

becoming more negative and larger with the increase of TEP, NM and $n$-BTN composition. The ion-solvent behaviour of $\mathrm{Cu}^{+}$in $\mathrm{AN}+n$-BTN mixtures is similar to that in $\mathrm{AN}+\mathrm{NM}, \mathrm{AN}+\mathrm{TEP}, \mathrm{BN}+\mathrm{TEP}$ and $\mathrm{PY}+\mathrm{TEP}$ mixtures, but different from that observed in $\mathrm{AN}+\mathrm{DMF}$ and $\mathrm{AN}+\mathrm{DMSO}$ mixtures.

\section{Conclusions}

$\mathrm{Cu}^{+}, \mathrm{Na}^{+}, \mathrm{R}_{4} \mathrm{~N}^{+}$and $\mathrm{Ph}_{4} \mathrm{~B}^{-}$ions show strong ion-solvent interactions in $\mathrm{AN}+n$-BTN mixtures. In the cases of $\mathrm{Na}^{+}$and $\mathrm{Cu}^{+}$this interaction seems to be mainly due to electrostatic ion-dipole interaction. The interaction between $\mathrm{R}_{4} \mathrm{~N}^{+}$and $\mathrm{Ph}_{4} \mathrm{~B}^{-}$ions with the solvent molecules appears to be mainly due to hydrophobic or dispersion forces. All anions interact weakly with the solvent molecules in $\mathrm{AN}+n$-BTN mixtures.

\section{Acknowledgement}

AK thanks the CSIR, New Delhi for the award of a JRF.

[3] D. Das, B. Das, and D. K. Hazra, J. Sol. Chem. 31, 425 (2002).

[4] D. S. Gill, R. Singh, H. Anand, and J. K. Puri, J. Mol. Liq. 98-99, 15 (2002). 
[5] M. S. Chauhan, G. Kumar, S. Chauhan, and S. Gupta, Indian J. Chem. 43A, 734 (2004).

[6] D. S. Gill, H. Anand, A. Kumari, and J. K. Puri, Z. Naturforsch. 59a, 615 (2004).

[7] A. J. Parker, I. D. MacLeod, D. Muir, and P. Singh, Australian J. Chem. 30, 1423 (1977).

[8] D. S. Gill, R. Singh, and I. M. Joshi, Indian J. Chem. 39A, 579 (2000).

[9] A. J. Parker, Search 4, 426 (1973).

[10] H. L. Yeager and B. Kratochvil, J. Phys. Chem. 73, 1963 (1969).

[11] D. S. Gill and J. S. Cheema, Z. Phys. Chem. (N.F.) 134, 205 (1983).

[12] D. S. Gill, V. Pathania, A. Kumari, H. Anand, and S. P. Jauhar, Z. Phys.Chem. 218, 857 (2004).

[13] D. S. Gill, H. Anand, and J. K. Puri, J. Mol. Liq. 108, 265 (2003).

[14] M.S. Chauhan, K. Sharma, and G. Kumar, Indian J. Chem. 41A, 483 (2002).

[15] J. A. Riddick, W. B. Bunger, and T. K. Sakano, Organic
Solvents, Physical Properties and Methods of Purification, $4^{\text {th }}$ ed., Wiley Interscience, New York 1986.

[16] B. J. Hathaway, D. G. Holah, and J. D. Postlethwaite, J. Chem. Soc. 3215 (1961).

[17] D.S. Gill and J.S. Cheema, Electrochim. Acta. 27, 1267 (1982).

[18] D. S. Gill, A. N. Sharma, and H. Schneider, J. Chem. Soc. Faraday Trans. 78, 465 (1982).

[19] I. Davidson, G. Perron, and J. E. Desnoyers, Canad. J. Chem. 59, 2212 (1981).

[20] R. Zana, G. Perron, and J. E. Desnoyers, J. Sol. Chem. 9, 59 (1980).

[21] D.S. Gill and M. B. Sekhri, J. Chem. Soc. Faraday Trans. I. 78, 119 (1982).

[22] F. Millero, J. Phys. Chem. 75, 280 (1971).

[23] J. Singh, T. Kaur, D. S. Gill, and V. Ali, J. Chem. Soc. Faraday Trans. 90, 579 (1994).

[24] K. Bose and K. K. Kundu, Indian J. Chem. 17A, 122, 1979. 